\title{
Compensation for Loss of Commodity Value: Theoretical and Practical Aspects
}

\author{
Sadykov I. F. ${ }^{1}$, Aletkin P. A. ${ }^{1} \&$ Astrakhantseva E. A. ${ }^{1}$ \\ ${ }^{1}$ Kazan Federal University, Institute of Management, Economics and Finance, Kazan, 420008, Russia \\ Correspondence: Sadykov I. F., Kazan Federal University, Institute of Management, Economics and Finance, \\ Kazan, 420008, Russia. Tel: 7-917-390-7976. E-mail: ildar_sad@mail.ru
}

Received: December 27, 2014 Accepted: February 19, 2015 Online Published: April 30, 2015

doi:10.5539/ass.v11n11p95

URL: http://dx.doi.org/10.5539/ass.v11n11p95

\begin{abstract}
The article describes the legal and practical aspects of compensation for loss of commercial value in the implementation of insurance benefits under compulsory civil liability insurance of vehicle owners and the court practice on this issue in relation to the previous and the current editions of the normative-legal acts regulating mandatory liability insurance of vehicle owners. Suggestions have been made in terms of eliminating the problem for insurance companies and for the legislator. It is concluded that the issue of compensation for loss of commercial value after the new editions of the normative legal acts in the area of concern remains unresolved.
\end{abstract}

Keywords: loss of commodity value, insurance, CTP, civil liability, court practice

\section{Introduction}

It's no secret that the situation with the insurance payments in Russian Federation is far from being the best way. The reason is not only and not so much in the fact that insurance companies behave incorrectly with respect to the beneficiary but the lack of a legislative settlement of the issue of such payments. This is particularly evident in the field of compulsory insurance of civil liability of owners of vehicles, or, in common, CTP.

The issues of compulsory insurance of civil liability considering country-specific factors were addressed by many researchers: Vostatek, J., Ognjanovic, S., De Poorter I., Faure M. G. Currently existing economic studies in Russia are dedicated mostly to accounting issues Vetoshkina E. Yu and Tukhvatullin R. S., Kulikova L. I., Ivanovskaya A. V. and Antonova N. V., Aletkin P. A. but rarely cover insurance problems.

\section{Purpose and Method}

The aim of the research is to demonstrate the imperfection of Russian law enforcement system in respect to compensation for loss of commercial value on the basis of analysis and synthesis of existing legal acts, as well as a comparative analysis with the previous versions of legal acts in the area of concern.

\section{Theory}

According to subparagraph "b" of paragraph 2.1 (previous version, date until September 1, 2014) and the corresponding subparagraph "b" of paragraph 18 (new version in force since September 1, 2014) of Article 12 of the Federal Law of April 25, 2002 № 40-FZ "On mandatory insurance of civil liability of vehicle owners" (Vostatek, 1996) (hereinafter: Law on CTP), in case of damage to property the size of the victim damages is determined by the amount of costs necessary to bring the property to the state in which it was before the insured event. In paragraph 2.2 (previous version) and in the corresponding paragraph 19 (revised) of the same article specific types of expenses and the procedure for their determination are provided.

The above provision of the previous edition of the Law corresponds to subparagraph "b" of paragraph 63 of the previously existing Rules for compulsory insurance of civil liability of vehicle owners, approved by the Government of the Russian Federation on May 7, 2003 N-263, and the corresponding provision of the current version of the Law corresponds with paragraph 4.15 existing rules of compulsory insurance, approved by the Bank of Russia on September 19, 2014 N 431-P (hereinafter: the Rules of CTP), according to which in the event of damage to the property of the victim the amount of insurance payments is determined "in the amount of the expenditures required to bring the property into a state in which it was before the insured event (remedial costs)".

At the same time as the loss due to be compensated must appear the loss of commodity value (hereinafter: LCV), which is confirmed by the validity of the explanation of the Supreme Court, by the data in the judicial review of the Supreme Court for the second quarter of 2005 (in civil cases), approved by the Decree of the Presidium of 
the Supreme Court of August 10, 2005 (the answer to question 18), according to which "the loss of commodity value is a decrease in the value of the vehicle caused by premature deterioration of the marketable (external) condition of the car and its performance as a result of the strength reduction and longevity of individual parts, components and assemblies, connections and protective coatings due to a traffic accident and subsequent repair" which implies that "the loss of commercial value relates to the real damage along with the cost of repair and spare parts of the car as the reduction of its use value violates the rights of the owner of the vehicle. This violated right can be restored by monetary compensation. The owner has the right to assert the claims for the recovery of such compensation as his rights were violated by the very fact of the accident".

A similar provision is set out in the Decision of the Supreme Court of July 24, 2007 N GKPI07-658, upheld by the Cassation Chamber of the Supreme Court of the Russian Federation dated November 6, 2007 N KAS07-566, according to which paragraph 63 of the Rules CTP was declared partially invalid in respect to the provision that excluded the loss of commercial value of the victim from the insurance payment in case of property damage.

The above position is confirmed by the fact that in accordance with Article 1082 of the Civil Code of the Russian Federation (Kulikova, Ivanovskaya, \& Antonova, 2014) (hereinafter: the Civil Code), paragraph 1 of Article 15 of the Civil Code (Vetoshkina \& Tukhvatullin, 2014), the person whose rights were violated may demand full compensation for damages if law or contract doesn't provide indemnification in a smaller size. According to paragraph 2 of Article 15 of the Civil Code the loss is the expenses made or will be made by the person to redress the violated right or damage to its property (real damage). These losses, in particular, include loss of commercial value as well.

\section{Practice}

In practice, however, until recently, all were different. De facto, despite the aforementioned jurisprudence of the Supreme Court voluntary compensation for the loss of the commercial value has not happened when victims addressed to insurance companies on CTP. All of the victims were sent to the courts for protection of their rights. The insurance companies didn't make voluntary payments.

But the problem also exists on the legislative level because of the differences of special and general rules set out in the Law on CTP and the Civil Code. At the same time because of the unresolved issue of special rules in the form of the Law on CTP where compensations for the loss of commercial values are not spelled out clearly, there were common situations when insurance companies operating in compliance with the law did not make compensations on a voluntary basis on the grounds that no the Law on CTP nor the Rules of CTP compensation of such damages are not explicitly spelled out, and they have the obligation to reimburse only those damages mentioned in the Law on CTP.

Nevertheless, the position of insurance companies which having received a complaint from the victim of incomplete insurance cover do not exercise his insurance payment while being perfectly aware that the above amount of compensation for the loss of commercial value will be charged from the insurer in court is not understandable. The situation when the victim appeals to an independent appraiser to obtain the information about the amount of the compensation for the loss of commercial value and bears additional costs that no one other than the insurer reimburses and thus his compensation in the event of failure of the insurer will have to be charged in court is not understandable as well.

In other words, the fact that the treatment of the victim against the insurer with a valid claim supported by the report of an independent appraiser is a clear indication of his intention to go to court to protect his rights in the event when "getting the truth" from the insurance company is not working.

The decisions of the courts before the Law on CTP was amended and before the release of the new Rules on CTP were known in advance, and otherwise ordinary courts could not deliver a judgment because of the articulated above position of the Supreme Court. The courts recovered from the insurer not only the underpaid amount including the loss of the commercial value but the penalty in accordance with the second subparagraph of paragraph 2 of Article 13 of the Law on CTP, moral damages for violation of consumer rights under Article 15 of the Law of the Russian Federation of February 7, 1992 N 2300-I On Protection of Consumers' Rights (Ognjanovic, Avdagic, Ognjanovic, \& Radic, 2012) (hereinafter : Law on Consumer Protection), a penalty of 50\% of the sum awarded in accordance with paragraph 6 of Article 13 of the Law on Consumer Protection, as well as legal costs, in accordance with article 98 of the Civil Procedure Code of the Russian Federation (Aletkin, 2014) (hereinafter: the Code of Civil Procedure Code).

And if you can understand the position of insurers in case of appeal of the victim in the situation of the absence of the report of an independent appraiser of the damage, then in the case of the presence of such an evaluation 
the logic of insurance companies is not clear in principle. After all consciously making losses they contribute to the fact that insurance becomes more expensive for themselves as a business segment. But all you need to do is to pay immediately the amount of insurance compensation to cover actual damages which includes the loss of commercial value.

Another important issue is that the vast majority of citizens of Russian Federation are legally illiterate and the problem is not that they do not know their rights but they do not know how to use them properly. Also many people are not aware of what is real damage, how to confirm it and do not know the fact that the loss of commercial value is a part of the real damage. And even if the victim knows all this he still needs to find a lot of time to defend his rights: to find an appraiser, to conclude a treaty with him, to get a report of the damage, submit a valid claim against the insurer, to be refused, to make a claim either hire lawyer to make such a statement, to file a lawsuit to court, to pay the services of a representative or attend court himself. All of this is a huge waste of time, and for the working population being engaged in all of these actions in order to receive a negligible amount of damage costs more than the payments that they receive on a court decision given that the costs of the representative have to be reimbursed in accordance with article 100 of the Civil Procedural Code of the Russian Federation in "reasonable limits ", i.e. they will be de facto "cut" by the judge as he pleases which can make the claim not having economic sense despite all the penalties applied by the court in relation to the defendant.

This explains the position of insurers when dealing with the small amounts of claims by victims, but does not explain their actions in case of significant amount of damage, i.e. when the probability of filing the lawsuit of the victim in court is greater than ever. Especially when in court the penalty was exacted from the insurer and a fine of $50 \%$ of the awarded amount. Nevertheless, it should be noted that the current legislation is still imperfect in this aspect and de facto doesn't provide protection of legal interests of its citizens during the pre-trial settlement procedure because of the existing interpretation given in a special standard (Law on CTP).

\section{Results}

Amending the Law on CTP towards clarification of its provisions and greater specificity would make the existing legislation more transparent, would protect the rights of citizens, would have avoided such an influx of claims which takes place at the present time as the courts are downloaded with the claims for damages upon traffic accidents that results in underpayment of insurance benefits. This issue was recently raised at the legislative level through the introduction of bills for discussion of the State Duma which resulted in the birth of a new edition of the Law on CTP. It was assumed that the civil law in the matter of compensation of property damage, including the issues of compensation for loss of commercial value, will undergo a welcome change.

\section{Conclusions}

Table 1. Comparison of the editions of the Law on CTP and the Rules of CTP on the issue of guarantees of compensation for the loss of commercial value

\begin{tabular}{ccc}
\hline Comparison criterion & $\begin{array}{c}\text { The previous edition of the Law } \\
\text { and the Rules of CTP }\end{array}$ & $\begin{array}{c}\text { The new edition of the Law and the } \\
\text { Rules of CTP }\end{array}$ \\
\hline $\begin{array}{c}\text { Securing in a legal act of the } \\
\text { specific rules regarding } \\
\text { compensation for the loss of } \\
\text { commercial value } \\
\begin{array}{c}\text { Voluntary reimbursement by } \\
\text { insurance companies the loss of } \\
\text { commercial value }\end{array}\end{array}$ & $\begin{array}{c}\text { No specific rules } \\
\text { Insurers do not cover voluntary } \\
\text { loss of commercial value }\end{array}$ & $\begin{array}{c}\text { Insurers do not cover voluntary loss } \\
\text { of commercial value }\end{array}$ \\
$\begin{array}{c}\text { Law enforcement practice in the } \\
\text { matter of compensation for the loss } \\
\text { of commercial value }\end{array}$ & $\begin{array}{c}\text { There is a legal practice in favor of } \\
\text { car owners }\end{array}$ & $\begin{array}{c}\text { Previous law enforcement practice } \\
\text { will be accounted or will undergo } \\
\text { changes }\end{array}$ \\
\hline
\end{tabular}

However in the new edition of the Law the issues of compensation for the loss of commercial value have remained unresolved. Moreover the existed explanations of the Supreme Court explicitly referred to the relevant provisions of the Law on CTP and Rules on CTP but nowadays the lawyers have to draw an analogy between the previous and the current edition of the above-mentioned legal acts for the application of explanations of the 
Supreme court to the new conditions. Clearly the situation is systemized in table 1 . We want to believe that the current enforcement practices in the matter of compensation for the loss of commercial value will be accounted in the new relations in the field of liability insurance and previous experience will be considered.

As a result currently there is a situation when a new law enforcement practice has yet to emerge and the consumers of insurance services have fewer guarantees of reimbursement of actual damage compared to what it was before the release of new versions of the legal acts.

\section{References}

Aletkin, P. A. (2014). International Financial Reporting Standards Implementation into the Russian Accounting System. Mediterranean Journal of Social Sciences, 5(24), 33-37.

Kulikova, L. I., Ivanovskaya, A. V., \& Antonova, N. V. (2014). Efficiency Analysis of Taking out Real Estate Loans for Profit-Making Organizations. Mediterranean Journal of Social Sciences, 5(24), 70-74.

Ognjanovic, S., Avdagic, M., Ognjanovic, D., \& Radic, M. (2012). The determination of the damage compensation for people according to the special rules within the mandatory traffic insurance the Estern Europe. Technics Technologies Education Management, 7(4), 1865-1874.

Vetoshkina, E. Yu., \& Tukhvatullin, R. S. (2014). The Problem of Accounting for the Costs Incurred after the Initial Recognition of an Intangible Asset. Mediterranean Journal of Social Sciences, 5(24), 52-55.

Vostatek, J. (1996). Motor liability insurance: Quo vadis? Finance a Uver, (5), X3-292.

\section{Copyrights}

Copyright for this article is retained by the author(s), with first publication rights granted to the journal.

This is an open-access article distributed under the terms and conditions of the Creative Commons Attribution license (http://creativecommons.org/licenses/by/3.0/). 